\title{
The Influence of Open-Ended Approach with Group- To-Group Strategy on the Improvement of Mathematic Communication Skills for High School Students
}

\author{
Emilianus Jehadus ${ }^{1}$, Maximus Tamur ${ }^{2}$, Viviana Murni ${ }^{3}$, Fransiskus Nendi ${ }^{4}$ and Sabina \\ Ndiung 5 \\ \{emiljehadus@unikastpaulus.ac.id ${ }^{1}$, maximustamur@unikastpaulus.ac.id ${ }^{2}$ \}
}

Universitas Katolik Indonesia Santu Paulus Ruteng, Jl. A. Yani No 10 Ruteng ${ }^{12345}$

\begin{abstract}
An open-ended approach with a group-to-group strategy has been used to support increased understanding, reasoning, and mathematical problem-solving abilities. However, experimentation on the effectiveness of this approach has not been explored much in supporting the improvement of students' mathematical communication skills. This experimental study aims to compare the mathematical communication skills of students who receive the open-ended group-to-group strategy treatment to students who receive conventional learning. This study involved 75 students in Wae Nakeng Santa Familia Senior High School, West Manggarai Regency, Indonesia. The data were collected by means of tests, and the t test was applied to compare the abilities of the two groups. Based on the results of the analysis, it can be concluded that the mathematical communication skills of students who accept open-ended with the group-to-group plan method are better than students in conventional classes.
\end{abstract}

Keywords: Open-ended approach; Group-to-group strategy; Mathematical communication skills

\section{Introduction}

Today the nations of the world focus on so many creative issues that communication is an essential skill that everyone in the 21st century must have [1]-[3]. Communication skills are fundamental in modern society because they are related to adaptation skills in dealing with various situations or problems [4]. Communication skills are also associated with increased problem-solving abilities, central to learning mathematics [5], [6]. Thus, understanding mathematical communication skills must be developed and improved.

Students' mathematical communication skills can be used to (1) organize and connect their mathematical thinking through communication; (2) communicate logical and clear mathematical thinking to friends, teachers, and others; (3) analyzing and assessing mathematical thinking and strategies used by others; and (4) using mathematical language to express the idea correctly [5]. The development of students' mathematical communication skills impacts increasing their overall intelligence [7]. It is the teacher's duty to condition mathematics learning which is oriented towards developing students' mathematical communication skills. 
Expectations to develop students' mathematical communication skills do not appear to be matched by practitioners' efforts to learn mathematics in the classroom. Recent studies have found that mathematics has been conceptualized and presented as a collection of content [8]. As a result, the learning pattern was carried out, and the teacher emphasized lecturing and memorizing formulas. If this is allowed to do so, then the hope of giving birth to a generation that can compete in the 21 st century will not be achieved.

Highlighting this problem, the teacher must strive to develop students' mathematical communication skills. Like most students' mathematical abilities, communication skills can be developed using appropriate learning models [9]-[15]. Related to that, [16]-[19] suggested that learning that regulates students to work in groups by discussing open problems can support students' mathematical communication skills. One learning strategy that fulfills these suggestions is an open-ended approach with a group-to-group strategy. The open-ended approach with group-to-group strategy conditions students to think, cooperate, adapt, solve problems, communicate, and share information with others [20].

Previous research has applied an open-ended strategy to various mathematical abilities of students [21]-[25]. The researchers found that an open-ended strategy combined with a student-centered approach improved students' creative thinking, reasoning, and mathematical problem-solving abilities. Unfortunately, in the literature, there are no studies that specifically question the effect of an open-ended strategy combined with a group-to-group approach on students' mathematical communication skills. This study was conducted to expand previous related research, focusing on analyzing the effects of an open-ended approach with a group-togroup strategy on students' mathematical communication skills.

\section{Methodology}

Under the research objectives that have been set above, this type of research is quantitative, namely research that uses numerical information in the form of data collection and data interpretation to process and summarize information [26]. The research method used was experimental research with a Posttest-Only Control Group Design research design with a scheme suggested by [27] as illustrated in Table 1.

Table 1. Posttest-Only Control Group Design

\begin{tabular}{|c|c|c|}
\hline Class & Independent Variable & Post-test \\
\hline Experiment & $\mathrm{X}$ & $\mathrm{Y}_{2}$ \\
\hline Control & - & $\mathrm{Y}_{2}$ \\
\hline
\end{tabular}

Information:

$\mathrm{X} \quad$ : Treatment by applying models open-ended approach with group-to-group strategy.

Y2 : Posttest two classes.

\subsection{Participant}

The population in this study were all grade 75 students of class XI SMA Katolik Santa Familia Wae Nakeng, West Manggarai Regency, Indonesia, spread over 5 (five) classes. The sample in this study consisted of two randomly selected classes (random class), namely the XI IPS 1 class with 38 students as the experimental class and the XI IPS3 class with 37 students as the control class. Previously, the class equivalence test had been carried out by providing a preliminary test. The data were analyzed using the separated variants formula. The results of 
the data analysis show that all classes are equal in terms of their mathematical communication skills.

\subsection{Instrument}

The instrument used was a five (5) number essay test. This test was given at the end of the research activity in order to obtain data about the students' mathematical communication skills. This test instrument is prepared based on indicators of mathematical communication skills, and previously tested its validity and reliability tests. The data in this study were obtained from the test results of students' mathematical communication skills from the experimental class and control on the derivative function material that was given after the learning was complete. The data analysis used was descriptive and inferential statistical analysis. Hypothesis testing, namely the difference test is carried out through the t-test with a significance level of 0.05 where previously the prerequisite test was the normality test which was carried out by comparing the calculated Chi with the Chi table, with degrees of freedom $=$ $\mathrm{k}-1$ and $\alpha=0.05$, and homogeneity test using the Fisher test.

\section{Result and Discussion}

Based on the data obtained through the pretest, an analysis of the mean differences in mathematical communication skills was carried out between the experimental class that took part in learning using an open-ended group-to-group approach and the control class that followed conventional learning. Table 2 shows the pretest and posttest mathematical communication skills in derivative learning for the two groups.

Table 2. The results of the pretest and posttest

\begin{tabular}{cccccccccc}
\hline & & \multicolumn{4}{c}{ Pre-test } & \multicolumn{5}{c}{ Post-test } \\
\cline { 3 - 11 } Class & SDI $^{*}$ & $\bar{x}$ & $s$ & $X_{\text {Min }}$ & $X_{\text {Max }}$ & $\bar{x}$ & $s$ & $X_{\text {Min }}$ & $X_{\text {Max }}$ \\
\hline Experiment & 24 & 4,32 & 1,73 & 1 & 7 & 19,72 & 2,26 & 17 & 24 \\
Control & 24 & 3,68 & 1,60 & 0 & 6 & 12,72 & 2,35 & 8 & 17 \\
\hline
\end{tabular}

* Note: SDI $=$ Ideal Score

Table 2 shows that descriptively students who get an open-ended approach with groupto-group learning are better than students who get conventional learning. However, statistical tests need to be applied to analyze the significance of the differences. For this reason, the prerequisite test, namely the normality and homogeneity test, is carried out first. Tables 3, 4, and 5 each show the normality test results, homogeneity test, and T-test with a significance of 0.05 .

Table 3. Data normality test of students' mathematical communication skills

\begin{tabular}{cccc}
\hline Class & $\mathrm{N}$ & $x_{\text {count }}^{2}$ & $x_{\text {table }}^{2}$ \\
\hline Experiment & 38 & 9,8247 & 24,0749 \\
Control & 37 & 10.7561 & 23,2686 \\
\hline
\end{tabular}

* Note: $\mathrm{N}=$ number of participants

Based on Table 3, it can be seen that count $x \_$count ${ }^{\wedge} 2<x \_t a b l e^{\wedge} 2$ which means that the two classes are normally distributed. 
Table 4. Homogeneity test of students' mathematical communication skills

\begin{tabular}{ccccc}
\hline Class & $\boldsymbol{\alpha}$ & $\boldsymbol{F}_{\text {count }}$ & $\boldsymbol{F}_{\text {table }}$ & Conclusion \\
\hline $\begin{array}{c}\text { Experiment } \\
\text { Control }\end{array}$ & 0,05 & 1,2516 & 1,8729 & Homogeneous \\
\hline
\end{tabular}

Based on Table 4, it can be seen that $F$ count $=1,2516<\llbracket F]$ (table $)=1,8729$, which means that the variance of the two classes is homogeneous. Furthermore, based on Table 2, the post-test average score of mathematical communication skills between the experimental class and the control class is quite far, namely $29.1 \%$. Hypothesis testing is done to see the differences in the mathematical communication skills of the experimental class and the control class. Table 5 shows the test for differences in the mathematical communication skills of the two classes. Parametric statistical tests were carried out by using the t-test with the hypotheses tested were:

$\mathrm{H}_{0}$ : Students' mathematical communication skills taught using the open-ended approach with group-to-group strategy are not better than those taught using conventional models.

$\mathrm{H}_{1}$ : Students' mathematical communication skills taught using the open-ended approach with group-to-group strategy are better than those taught using conventional models.

Table 5. Test the Difference in Students' Mathematical Understanding Ability

\begin{tabular}{ccccc} 
Class & $N$ & $\alpha$ & $t_{\text {count }}$ & $t_{\text {table }}$ \\
\hline Experiment & 38 & 0,05 & 2,1607 & 1,2694 \\
Control & 37 & & & \\
\hline
\end{tabular}

Based on Table 5, it can be seen that $t \_c o u n t>t$ table which means $\mathrm{H} 0$ is rejected or H1 is accepted. Thus, students' mathematical communication skills taught using the open-ended approach with group-to-group strategy are better than those taught using conventional models. This study explains that the mathematical communication skills of students who are taught using an open-ended approach with group-to-group on derivative function material are higher than the mathematical communication skills of students taught by conventional learning. This result is supported by related studies conducted previously, such as [21], [24], [25].

Although this study was conducted at different places and times, it gives similar results. This means that there is a clear trend that the open-ended approach with group-to-group models makes a positive contribution to improving student academic performance. The openended approach with group-to-group breathes constructivism. It is a common phenomenon for now that constructivism-based learning models support the development of student academic performance [28]-[31].

\section{Conclusion}

This study was conducted to analyze the effect of an open-ended approach with group-togroup on students' mathematical communication skills. Based on the results of the analysis, it was concluded that the students' mathematical communication skills taught using the openended approach with a group-to-group strategy were better than those taught using 
conventional models. This open-ended approach with group-to-group can foster cooperation among students, so that in the learning process students will become more active in communicating, assessing the opinions of others, and expressing their ideas openly. Future research should consider the analysis of variance by examining separately the role of the openended model and the group-to-group approach. This is done to get a clear picture of between these two treatments.

\section{Acknowledgments.}

Thank you to the Santu Paulus Foundation for funding this research

\section{References}

[1] Nurjanah, B. Latif, R. Yuliardi, and M. Tamur, "Computer-assisted learning using the Cabri 3D for improving spatial ability and self- regulated learning," Heliyon, vol. 6, no. 11, p. e05536, 2020, doi: 10.1016/j.heliyon.2020.e05536.

[2] R. Wiemken, R. Sri Padmi, and G. Matney, "Global Connections through Mathematical Problem Solving," Math. Teach. Learn. Teach. PK-12, vol. 114, no. 3, pp. 219-226, 2021, doi: 10.5951/mtlt.2020.0097.

[3] M. Tamur, "Pembelajaran Kooperatif Tipe STAD Berbasis Etnomatematika Sebagai Upaya Meningkatkan Kemampuan Pemahaman Dan Komunikasi Matematis Mahasiswa PGSD: Mengintegrasikan Tarian Caci Ke Dalam Bahan Ajar Di STKIP St Paulus Ruteng-Flores NTT," Universitas Pendidikan Indonesia, 2012.

[4] V. A. Reed and S. Trumbo, "The Relative Importance of Selected Communication Skills for Positive Peer Relations: American Adolescents' Opinions,” Commun. Disord. Q., vol. 41, no. 3, pp. 135-150, 2020, doi: 10.1177/1525740118819684.

[5] N. Rohid, S. Suryaman, and R. D. Rusmawati, "Students' Mathematical Communication Skills (MCS) in Solving Mathematics Problems: A Case in Indonesian Context," Anatol. J. Educ., vol. 4, no. 2, pp. 19-30, 2019, doi: 10.29333/aje.2019.423a.

[6] N. Susanti, D. Juandi, and M. Tamur, "The Effect of Problem-Based Learning ( PBL ) Model On Mathematical Communication Skills of Junior High School Students - A Meta-Analysis Study," JTAM (Jurnal Teor. dan Apl. Mat., vol. 4, no. 2, pp. 145-154, 2020, doi: 10.31764/jtam.v4i2.2481.

[7] A. A. Rahman et al., "Retracted: Improve the Students' Mathematics Communication Ability Using Realistic Mathematics Education,” J. Phys. Conf. Ser., vol. 1114, no. 1, p. 012112, 2018, doi: 10.1088/1742-6596/1114/1/012112.

[8] Y. Li and A. H. Schoenfeld, "Problematizing teaching and learning mathematics as 'given' in STEM education," International Journal of STEM Education, vol. 6, no. 1. pp. 1-13, 2019, doi: 10.1186/s40594-019-0197-9.

[9] S. M. Freeman-Green, C. O'Brien, C. L. Wood, and S. B. Hitt, "Effects of the SOLVE strategy on the mathematical problem solving skills of secondary students with learning disabilities," Learn. Disabil. Res. Pract., vol. 30, no. 2, pp. 76-90, 2015, doi: 10.1111/ldrp.12054.

[10] M. Tamur and D. Juandi, "Effectiveness of Constructivism Based Learning Models Against Students Mathematical Creative Thinking Abilities in Indonesia: A Meta-Analysis Study," Pervasive Heal. Pervasive Comput. Technol. Healthc., no. 1, pp. 107-114, 2020, doi: 10.4108/eai.12-10-2019.2296507.

[11] Suparman, D. Juandi, and M. Tamur, "Does Problem-Based Learning Enhance Students ' Higher Order Thinking Skills in Mathematics Learning? A Systematic Review and Meta-Analysis," in 2021 4th Inter- national Conference on Big Data and Education (ICBDE'21), 2021, pp. 44-51, doi: $10.1145 / 3451400.3451408$.

[12] M. Tamur, D. Juandi, and Y. S. Kusumah, "The Effectiveness of the Application of Mathematical Software in Indonesia: A Meta-Analysis Study,” Int. J. Instr., vol. 13, no. 4, pp. 867-884, 2020, [Online]. Available: http://www.e-iji.net/dosyalar/iji_2020_4_53.pdf. 
[13] S. Suparman, D. Juandi, and M. Tamur, "Review of problem-based learning trends in 2010-2020 : A meta-analysis study of the effect of problem-based learning in enhancing mathematical problemsolving skills of Indonesian students," J. Phys. Conf. Ser., vol. 1722, no. 1, p. 012103, 2021, doi: 10.1088/1742-6596/1722/1/012103.

[14] D. Juandi et al., "The Effectiveness of Dynamic Geometry Software Applications in Learning Mathematics: A Meta- Analysis Study,” Int. J. Interact. Mob. Technol., vol. 15, no. 02, pp. 18-37, 2021, doi: 10.3991/ijim.v15i02.18853.

[15] M. Tamur, Y. S. Kusumah, D. Juandi, T. T. Wijaya, A. Nurjaman, and A. O. Samura, "Hawthorne effect and mathematical software based learning: A meta- analysis study," J. Phys. Conf. Ser., vol. 1806, no. 1, p. 012072, 2021, doi: 10.1088/1742-6596/1806/1/012072.

[16] O. H. Bolstad, "Secondary teachers' operationalisation of mathematical literacy," Eur. J. Sci. Math. Educ., vol. 8, no. 3, pp. 115-135, 2020.

[17] M. Tamur, E. Jehadus, H. R. P. Negara, M. D. Siagian, M. Marzuki, and R. Sulastri, "Pembelajaran Selama Krisis COVID - 19 : Meta - Analisis dari Sudut Hasil Belajar yang Diukur,” J. Ris. Teknol. dan Inov. Pendidik., vol. 4, no. 1, pp. 101-108, 2021, doi: 10.36765/jartika.v4i1.413.

[18] M. F. B. Paloloang, D. Juandi, M. Tamur, B. Paloloang, and A. M. G. Adem, "Meta Analisis: Pengaruh Problem-Based Learning Terhadap Kemampuan Literasi Matematis Siswa Di Indonesia Tujuh Tahun Terakhir,” AKSIOMA J. Progr. Stud. Pendidik. Mat., vol. 9, no. 4, pp. 851-864, 2020, doi: 10.24127/ajpm.v9i4.3049.

[19] M. Tamur, D. Juandi, and A. M. G. Adem, "Realistic Mathematics Education in Indonesia and Recommendations for Future Implementation: A Meta-Analysis Study," J. Teor. dan Apl. Mat., vol. 4, no. 1, pp. 17-27, 2020, doi: 10.31764/jtam.v4i1.1786.

[20] O. Akinoğlu and R. Ö. Tandoğan, "The effects of problem-based active learning in science education on students' academic achievement, attitude and concept learning," Eurasia J. Math. Sci. Technol. Educ., vol. 3, no. 1, pp. 71-81, 2007, doi: 10.12973/ejmste/75375.

[21] N. Alfiani, Hafidzah, Za. Azis, and Irvan, "The Effect of Open Ended Approach On Problem Solving Ability and Learning Independence In Students ' Mathematics Lessons,” IJEMS Indones. J. Educ. Math. Sci., vol. 1, no. 1, pp. 44-50, 2021, doi: 10.30596/ijems.v1i3.2602.

[22] M. Triana, C. M. Zubainur, and B. Bahrun, "Students' Mathematical Communication Ability through the Brain-Based Learning Approach using Autograph," JRAMathEdu (Journal Res. Adv. Math. Educ., vol. 1, no. 1, pp. 1-10, 2019, doi: 10.23917/jramathedu.v1i1.6972.

[23] R. Johar, E. Junita, and S. Saminan, "Students' Mathematical Communication Ability and SelfEfficacy Using Team Quiz Learning Model,” Int. J. Emerg. Math. Educ., vol. 2, no. 2, p. 203, 2018, doi: 10.12928/ijeme.v2i2.8702.

[24] R. R. Sabrina, M. Iswari, and Yerizon, "The Influence of Open-Ended Approach to Mathematical Creative Thinking Ability of 5th Grade Students Elementary School in Padang," Adv. Soc. Sci. Educ. Humanit. Res., vol. 285, no. 1, pp. 282-284, 2018, doi: 10.2991/icm2e-18.2018.64.

[25] I. Putu Hendra Widiartana, "The Effect of Open-Ended Approach Towards Students' Mathematical Reasoning," J. Phys. Conf. Ser., vol. 1028, no. 1, p. 012134, 2018, doi: 10.1088/17426596/1028/1/012134.

[26] J. Bacon-Shone, Introduction to Quantitative Research Methods: A Gude for Research Postgraduate Students at The University of Hong Kong, no. February. 2015.

[27] D. Ary, L. C. Jacobs, C. Sorensen, and A. Razavieh, Introduction to Research in Education, 8th ed. Belmont USA: Wadsworth Publishing, 2010.

[28] E. Jehadus, M. Tamur, S. Jelatu, K. V Pantaleon, F. Nendi, and S. S. Defrino, "The Influence of Conceptual Understanding Procedures ( CUPS ) Learning Models Concept of Understanding of Concept Student Math," J. ofEducational Expert., vol. 3, no. 2, pp. 53-59, 2020, doi: 10.30740/jee.v3i2p53-59.

[29] M. Tamur, V. S. Kurnila, E. Jehadus, and S. Ndiung, "Learning from the Past: Meta-Analysis of Contextual Teaching-Learning of the Past Decade," vol. 4, no. 1, pp. 1-10, 2021.

[30] J. Pereira, Y. Huang, J. Chen, N. Hermita, and M. Tamur, "Learning the Concept of Absolute Value with Hawgent Dynamic Mathematics Software,” Tarbawi J. Ilmu Pendidik., vol. 16, no. 2, pp. 160 169, 2020, doi: 10.32939/tarbawi.v16i2.688. 
[31] M. Tamur, E. Jehadus, F. Nendi, K. Mandur, and V. Murni, "Assessing the effectiveness of the contextual teaching and learning model on students ' mathematical understanding ability : a metaanalysis study," J. Phys. Conf. Ser., vol. 1657, no. 1, p. 012067, 2020, doi: 10.1088/17426596/1657/1/012067. 